\title{
On the Ethical Implications and Political Costs of Misinterpreting and Abusing the Notion "Anti-Semitism"
}

\begin{abstract}
There is antisemitism in the world, even several distinct kinds of antisemitisms. There is also a lively discourse on what antisemitism is. This discourse, often inflamed, is pierced by both hypersensitivity and rejections, accusations and counteraccusations. Different groups have vested political interests both in launching accusations of antisemitism and in denying that certain propositions and actions are in fact antisemitic. The interrelations between actual real-life antisemitism and the discourse on antisemitism in media and public debate in general are subtle and complex. This article focuses on how the notion "antisemitism" in the contemporary era is sometimes used by different political interests as a vehicle for promoting certain political goals. By way of conclusion, the ethical implications and political costs for the Jewish people of the political exploitation of the fear Jews associate with real-life antisemitism is discussed.
\end{abstract}

In this article I will elaborate four points:

(1) The notion of "anti-Semitism." Taken literally, this term is in itself an antisemitically based notion. The quasi-racial idea it is based on is today largely discredited. Still the notions "anti-Semitism" and "antisemitism" have become firmly rooted. And still contempt and hatred of Jews persists. The very notion "anti-Semitism" and also, but to a lesser extent, the notion "antisemitism," at times serves the sophistry of some anti-Jewish agitators. It is necessary to sort out and to distinguish the persistent, however today not mainly racially motivated, Jew-hatred from other, often politically motivated uses and abuses of the notion "antisemitism."

(2) Besides carrying misleading racial connotations, and being at times politically abused, the notion "antisemitism" covers distinctly diverse phenomena. Although diverse, these phenomena are all expressions of particular kinds of Jew-hatred. In this article three such phenomena are distinguished. Since they are not strongly correlated, it is better speak of different antisemitisms. Each of these different kinds of antisemitism has its specific underlying "philosophy," its specific forms of manifestation, and its particular socially delimited carriers/ perpetrators.

(3) A functional, even if unintended, symbiosis appears to become established between, on the one hand, the interest of terrorists and other, violent Jewhaters who by their proclamations and actions cause anxiety and fear among Jews. And, on the other hand, some (understandably) alarmist Jewish voices. Among them are right-wing Zionists' and the Israeli government's often frivolous 
claims that Jews in the diaspora live in a fearful and basically antisemitic world in which a latent antisemitism constantly "shows its ugly face." Both sides, however for differing reasons, serve to underpin a sense of chronic fear and anxiety among diaspora Jews. From the one side, the fact that Jews constantly may fear being attacked is a calculated goal in itself; from the other side, underpinning the same feelings of constant fear may be intended to serve as a background for persuading Jews to leave the country in which they live and move to Israel as "the only safe place for Jews."

(4) There is a tendency of overusing, and at times even abusing, the term "antisemitism." This has potentially negative side effects for those who are, or potentially might be, targeted by actual Jew-hatred. By extending the notion "antisemitism" to cover also phenomena that are not directly expressions of Jewhatred, for example, opposition to certain policies and actions by the state of Israel, the concept of "antisemitism" becomes hollow and disarmed. As a consequence, there is a risk that people and institutions might not take even valid accusations of antisemitism seriously. 


\section{Terminology}

The notion "anti-Semitism” was coined by the German journalist Wilhelm Marr in a pamphlet published in 1879, titled Der Weg zum Siege des Germanenthums über das Judenthum (The Way to Victory of Germanism over Judaism). ${ }^{1}$ In his pamphlet, Marr introduced the idea that Germans and Jews were locked in a longstanding conflict, the origins of which he attributed to race. According to Marr, the struggle between Jews and Germans would only be resolved by the victory of one and the ultimate death of the other. In coining "anti-Semitism" he confused a linguistic term with a quasi-racial one. There are in fact Semitic languages, however there are no Semitic peoples or races. The term "anti-Semitism" was coined to denote a racially based fight against the Jews, and just Jews, as a supposed-as Marr saw it-dangerously intruding "race” in Germanenthum.

Marr founded a society called Die Anti-Semiten Liga as an organization in the service of that fight. ${ }^{2}$ The construction of and subsequently successfully dispersed term "anti-Semitism" meant a turning point in the history of Jew-hatred. Coinciding with the rapidly growing secularization of modern societies, it enabled a turn from the religiously based Christian hatred of Jews to a modern "scientifically" based contempt for Jews. Since Jews through this quasi-scientific optic were considered not only as inferior, but at the same time also as dangerous, it was no big step by extension to conclude that the threat Jews were supposed to pose should be eliminated by "necessary" hygienic operations. ${ }^{3}$

Today the quasi-scientific racist ideas catch little, or at least less, support. But still contempt and hatred of Jews persists. If not anymore primarily based on a quasi-scientific idea of race, then still manifesting itself in contempt and prejudices toward Jews and Jewish customs, in ideas of a threatening Jewish world conspiracy, and-not least-in actions and attacks on individual Jews and Jewish institutions with reference to policies and actions taken by the state of Israel.

Although a quasi-racially founded concept, "anti-Semitism" is still often, for example, by the English spelling control of my computer, spelled with a hyphen between "anti" and "Semitism"-as if "Semitism" were a real phenomenon of its own, such as socialism, liberalism, Zionism, or Judaism. Some of those who par-

1 This pamphlet by Wilhelm Marr (1819-1904) was published in several editions in the 1880s in Berlin by O. Hentze.

2 Cf. M. Zimmermann, Wilhelm Marr, the Patriarch of Anti-Semitism (Oxford: Oxford University Press, 1986).

3 Cf. Z. Bauman, Modernity and the Holocaust (Cambridge: Polity, 1991). 
ticipate in the contemporary public debate on Israel and hate crime against Jews, for example, my former teacher and colleague, the world renowned founder of peace research, professor Johan Galtung, do not refrain from the sophistry of claiming that Arabs cannot be anti-Semites because they are themselves "Semites." This type of argument implicitly acknowledges that it is based on a clearly quasi-racial concept.

Today the term, whether spelled "anti-Semitism" or "antisemitism," refers to standpoints and actions exclusively directed toward Jews. This might then be based on different mixtures in different persons of racial, religious, mythological, political, economic, and other images and prejudices. And could, as history shows, be driven all the way to wishing and acting to eradicate both Jews as living persons, and the Jewish people as such, and by implication also Judaism as a living religion and "Jewishness" as a mentality and lifestyle.

Since such tendencies exist in the world and constitute a unique phenomenon in itself, and since "anti-Semitism" is now an acknowledged term to denote this phenomenon, we have little choice but to use it, even if it is actually is a misconception. However, in order to avoid unnecessarily carrying along the possible misinterpretations and misunderstandings contained in Marr's conceptual invention-the unique phenomena of discrimination, contempt, hatred, fear, and obsession of Jews the term denotes-it should be conceived of and written as a concept in itself, without hyphen and capital letters: antisemitism.

In Anglo-Saxon literature the term "Judeophobia" is sometimes used as a synonym for antisemitism. This, however, is not a proper substitute: For some it may in fact be a kind of phobia, but most often a "phobia" is not the central element of antisemitism. A "phobia" by definition is a type of anxiety disorder, defined by a persistent fear of an object or situation. What usually is in play in antisemitism is something else. Rather than fear of Jews, antisemitism is usually an expression of contempt for, and even hatred toward Jews.

Realizing this distinction, some have contemplated terming this phenomenon "Jew-hatred." One practical advantage to doing so would be that the concept would be more congruent to the acknowledged concepts "hate speech" and "hate crime." However, antisemitism usually holds more sentiments and refers to other attitudes than just hate.

So even if it theoretically would be desirable to find a substitute for the concept "antisemitism," we for practical reasons will have to do with this term. A

4 For an extensive documentation of Galtung’s antisemitic declarations, cf. J. Færseth, "Johan and Antisemitism," Fri Tanke, November 12, 2020, https://fritanke.no/bakgrunn/johan-gal tung-and-antisemitism/19.11455. 
similar argument goes for the Greek term Holocaust, which means "A sacrifice consumed by fire"-taken literally, it is a fundamentally misleading concept since the mass killing of Jews by the Nazis was by no means a sacrifice. Jews today usually prefer to use the Hebrew word Shoah, that literally means "catastrophe." But since "Holocaust" today has become the acknowledged concept in the Anglo-Saxon literature to denote the systematic attempt at exterminating the Jewish people, for all practical purposes it also remains unavoidable to use, even if this by no means implies accepting the tacit "sacrifice" component of the concept.

\section{Antisemitisms}

A current, widely accepted working definition of antisemitism reads:

Antisemitism is a certain perception of Jews, which may be expressed as hatred toward Jews. Rhetorical and physical manifestations of antisemitism are directed toward Jewish or non-Jewish individuals and/or their property, toward Jewish community institutions and religious facilities. ${ }^{5}$

This is the working definition adopted by the International Holocaust Remembrance Alliance (IHRA) at their plenary meeting in Bucharest, on May 26, 2016.

A complication of this or any other definition of "antisemitism" is that it covers several distinctly diverse empirical phenomena. There are at least three different sources of contemporary contempt and hatred toward Jews that I have identified empirically. These are:

1. Classic stereotypes of Jews

2. "Aufklärungsantisemitismus"

3. Projections of the Israeli-Palestinian Conflict

In my reports Different Antisemitisms: Perceptions and experiences of antisemitism in Sweden and across Europe ${ }^{6}$ and Antisemitisms in the Twenty-First Century: Sweden and Denmark as Forerunners? ${ }^{7}$ on the 2012 and 2018 survey studies

5 "Working Definition of Antisemitism," International Holocaust Remembrance Alliance, issued May 26, 2016, https://www.holocaustremembrance.com/news-archive/working-definition-anti semitism.

6 Together with K. Marosi (London: Institute for Jewish Policy Research, 2017).

7 Cf. L. Dencik, "Antisemitisms in the Twenty-First Century: Sweden and Denmark as Forerunners?" in Antisemitism in the North: History and State of Research, ed. J. Adams and C. Hess (Berlin: De Gruyter, 2019), 231-66. 
by the European Agency for Fundamental Rights (FRA) on Discrimination and hate crime against Jews in EU member states, ${ }^{8}$ I have investigated the relative presence of these three kinds of antisemitism in several of today's European countries. I could then also conclude that these three antisemitisms are rather distinct, that is, not strongly empirically correlated. And furthermore, that each of them is based on disparate anti-Jewish images, becomes manifested and expressed in differing ways, and are carried by socially different kinds of perpetrators.

The three different kinds of antisemitisms I have delineated are classic antisemitism, Aufklärungsantisemitismus, and Israel-derived antisemitism.

\section{Classic Antisemitism}

This antisemitism is based on traditional antisemitic stereotypes about Jews. Those who manifest this kind of antisemitism are mainly found among political right-wingers. This kind of antisemitism mainly manifests itself in verbal derogatory personal or public remarks and acts of social discrimination.

One way of measuring this kind of antisemitism is by the scale used in a global survey study by the Anti-Defamation League in 2015. ${ }^{9}$ The scale consists of eleven statements to which the respondent can answer either "probably true" or "probably false." The statements are:

1. Jews are more loyal to Israel than to [this country/the countries they live in]

2. Jews have too much power in international financial markets

3. Jews have too much control over global affairs

4. Jews think they are better than other people

5. Jews have too much control over the global media

6. Jews are responsible for most of the world's wars

7. Jews have too much power in the business world

8. Jews don't care what happens to anyone but their own kind

9. People hate Jews because of the way Jews behave

10. Jews have too much control over the United States government

8 European Agency for Fundamental Rights (FRA), Discrimination and Hate Crime against Jews in EU Member States: Experiences and Perceptions of Antisemitism (Luxembourg: Publications Office of the European Union, 2014); idem, Experience and Perceptions of Antisemitism: Second Survey on Discrimination and Hate Crime against Jews in the EU (Luxembourg: Publications Office of the European Union, 2018).

9 “ADL Global 100,” Anti-Defamation League, accessed December 28, 2020, https://global100. adl.org/map. 
11. Jews still talk too much about what happened to them in the Holocaust

According to the criteria adopted by the ADL survey "respondents who said at least six out of the eleven statements are 'probably true' are considered to 'harbor anti-Semitic attitudes."”10

In short, they are classic antisemites. The ADL study finds out what proportion of the inhabitants in each of the investigated 101 countries are classic antisemites. I will here report only on those eight EU countries that participated in the first FRA survey. The data in the Table 1 below stems from 2015:

\begin{tabular}{lc}
\hline Hungary & 41 \\
France & 37 \\
Latvia & 28 \\
Belgium & 27 \\
Germany & 27 \\
Italy & 20 \\
UK & 8 \\
Sweden & 4 \\
\hline
\end{tabular}

Table 1: Percentage of the population in the some of the European countries harboring classic antisemitic attitudes according to the ADL index.

Noteworthy here is on the one extreme the high proportion of Hungarians who harbor classic antisemitic attitudes, and on the other extreme the relatively very low proportion of Swedes who do so.

The high number of classic antisemites in Hungary is not outstanding if compared to its neighboring east European countries such as Poland (45\%), Ukraine (38\%), Romania (35\%), Serbia (42\%), Bulgaria (44\%), and also Greece (69\%). Greece is actually the country outside the Middle East and North Africa with the highest Anti-Semitism Index Scores.

In contrast to this, the proportion of Swedes who qualify to be regarded as classic antisemitic is virtually the lowest registered in Europe and actually one of the very lowest in the entire world. ${ }^{11}$ On the whole the western European countries score considerably lower on the ADL Anti-Semitism Index Score than do the inhabitants in eastern Europe. And among the Western countries, the inhabitants in its perhaps most modernized and secular corner, ${ }^{12}$ the Scandinavian

10 Ibid.

11 Only two countries in the world manifest a lower Antisemitism Index Score than Sweden, viz. Laos $(0.2 \%)$ and the Philippines (3\%).

12 Cf. “Findings \& Insights,” The World Value Survey, accessed December 28, 2020, http://www. worldvaluessurvey.org/WVSContents.jsp?CMSID=Findings. 
countries, harbor less of classic antisemitic attitudes than in other parts of Europe.

\begin{tabular}{llllll}
\hline Denmark & $\mathbf{8} \%$ & Norway & $\mathbf{1 5 \%}$ & Sweden & $\mathbf{4} \%$ \\
\hline Men & 11 & Men & 21 & Men & 4 \\
Women & 6 & Women & 9 & Women & 3 \\
Age & & Age & & Age & \\
$18-34$ & 7 & $18-34$ & 8 & $18-34$ & 2 \\
$35-49$ & 4 & $35-49$ & 15 & $35-49$ & 1 \\
$50+$ & 12 & $50+$ & 20 & $50+$ & 7 \\
\hline
\end{tabular}

Table 2: Percentage of the population in Scandinavian countries harboring classic antisemitic attitudes according to the ADL index.

Noteworthy is the fact that men consistently score somewhat higher on classic antisemitism than women do and that there are more classic antisemitic attitudes among the older generation than among the younger adults.

It should be noted in this context that classic antisemitism is just one out of three distinct kinds of antisemitism. Even if classic antisemitism is more present in eastern European than in western European countries, we have in recent years experienced much more of antisemitic violence in West Europe than in East Europe. And even if classic antisemitism is less present in Sweden and Denmark than in all other European countries, antisemitic violence nonetheless has become manifested to a considerable degree in these countries.

Clearly something other than widespread classic antisemitic attitudes seem to be at play here. I will return to this discussion later in the article.

A special kind of anti-Jewish attitude has to do with negativism and prejudices against certain core Jewish practices. Today this is particularly widespread in the most liberal and enlightened countries of the world, such as the Scandinavian countries. The French historian Diana Pinto has labelled this kind of antiJewish attitude Aufklärungsantisemitismus. The German term for the Enlightenment is die Aufklärung. The background for using the German term here is the work Beantwortung die Frage: Was is Aufklärung? (Answering the Question: What is Enlightenment?) from 1784 by the groundbreaking German philosopher Immanuel Kant. 


\section{Aufklärungsantisemitismus}

Aufklärungsantisemitismus denotes critique, even to the extent of calling for prohibition, of core Jewish practices, such as the circumcision of baby boys (brit mila) and slaughtering of animals according to Jewish religious rules (shechita). Implied are accusations against Jewish representatives and individuals because of their adherence to such practices. Those who criticize these religiously based traditions are often persons who perceive themselves as progressive, liberal, leftoriented. This kind of anti-Jewish critique is usually presented as comments in public debate and at times, as recently in Iceland and Denmark, takes the shape of proposing legal prohibition of the Jewish practices in question. Shechita is today forbidden in all Scandinavian countries, whereas brit mila is not (yet), although there is widespread support in the general population of, for example, Denmark, to prohibit this Jewish tradition.

Aufklärungsantisemitismus is based on altogether different kinds of antiJewish attitudes than those that drive classic antisemitism. Those who advocate standpoints implied in Aufklärungsantisemitismus often argue in terms of the right of the child and animal protection and strongly oppose these standpoints be labelled antisemitic at all.

\begin{tabular}{ll}
\hline Sweden & 85 \\
Germany & 80 \\
UK & 61 \\
France & 59 \\
Italy & 52 \\
Belgium & 50 \\
Latvia & 22 \\
Hungary & 21 \\
\hline
\end{tabular}

Table 3: Percentage of Jews in the country having heard non-Jewish people suggest prohibition of brit mila or shechita. (Data from the 2012 FRA Survey).

We may here observe that the order of nations in Table 3 is almost a reversed version of the order of nations in Table 1. If Table 1 gives a picture of how classic antisemitism is distributed among the investigated European nations, Table 3 may be said to give a picture of how a kind of modern anti-Jewish sentiment is distributed among them.

History has shown that classic antisemitism in given social conditions may quite easily switch into pogroms and other violent acts against Jews. So far there are no known cases of Aufklärungsantisemitismus leading to acts of physical violence against Jews. 
The third kind of antisemitism that I want to demarcate as a particular, and by the way also a modern kind of antisemitism, Israel-derived antisemitism, on the other hand frequently finds violent outlets directed at individual Jews and Jewish institutions in Europe, the US, and virtually anywhere in the world. For Jews around the world, Israel-derived antisemitism is today the most threatening form of antisemitism.

\section{Israel-derived Antisemitism}

Israel-derived antisemitism refers to attacks on individual Jews or Jewish institutions just because they are Jewish, regardless of where they are. The attacks referred to here emanate from hostility of the perpetrators toward the state of Israel and/or anger due to actions taken by the Israeli state. To these perpetrators any Jew and anything Jewish around the world is perceived as somehow being in collusion with the state of Israel and hence in their eyes a relevant target for the perpetrators' hatred or anger toward the state of Israel. Those who carry out such attacks are mainly found among Muslim extremists and partly among political left-wingers. This kind of antisemitism is more often than the other forms of antisemitism manifested by acts of violence toward Jewish institutions, symbols, and persons.

A special circumstance to be aware of in this context is the fact that this kind of antisemitism, to be perceived as frightful and to cause individual Jews as well as communities to have to invest in means of precaution, is not necessarily a widespread phenomenon. Even if only manifested occasionally by a few individuals and groups, the constant fear at any time of becoming a victim of such actions understandably becomes widespread in Jewish circles.

To get an indication of how widespread attitudes potentially underpinning Israel-derived antisemitism might be in different countries are of interest. One indication might be the extent to which individual Jews in different countries are blamed for anything done by Israel. 


\begin{tabular}{llll}
\hline & overall, in \% & "frequently," in \% & "all the time," in \% \\
\hline Belgium & 62 & 45 & 17 \\
Italy & 59 & 42 & 17 \\
France & 58 & 38 & 20 \\
Sweden & 49 & 27 & 22 \\
Germany & 41 & 28 & 13 \\
UK & 36 & 26 & 10 \\
Hungary & 15 & 12 & 3 \\
Latvia & 6 & 5 & 1 \\
\hline
\end{tabular}

Table 4: Percentage of Jews who feel that people in their country accuse or blame them because you are Jewish for anything done by the Israeli government. (Data from the 2012 FRA Survey).

Interestingly, the rank order of the countries listed in Table 4 appears rather congruent with the degree to which antisemitic terrorist attacks have actually hit the Jewish populations in the countries listed in this table. Noteworthy is that the most antisemitic countries according to the ADL Anti-Semitism Index (cf. Table 1) such as Hungary and Latvia are those where Israel-derived antisemitism appears as the least represented. Whereas the reverse also seems to be true: Sweden is clearly the least antisemitic country as measured by the ADL Anti-Semitism Index, and Sweden is also the country with the largest proportion of Jewish respondents stating that they feel blamed for what Israel is doing "all the time"the proportion is $22 \%$ of the $49 \%$ who indicate they feel blamed-whereas in the country topping Table 4, Belgium, the corresponding figure is $17 \%$ of the $62 \%$ who feel blamed there.

Antisemitism is clearly not a homogenous concept. The three kinds of antisemitism I have defined are not strongly correlated. On the contrary, they become manifested by different kinds of perpetrators, they are carried by disparate "philosophies," and are expressed in quite different ways.

In trying to put "An end to Antisemitism!", that is, in order to adequately fight antisemitism as a real-life phenomenon, it is necessary not only to distinguish the different kinds of antisemitisms described above but also to clarify what kind of threat they pose, how each of them could be confronted, and in which order of priority, based on the threat they actually pose to Jews and Jewish life today.

One necessary prerequisite for achieving this goal is to stop using the term "antisemitism" in an imprecise and frivolous way, for instance as a political tool for blaming critics and opponents. This, however, is nowadays often done. 


\section{Abuses}

There is among some Jews an understandable hyper- or oversensitive registration of almost anything as expressions of "antisemitism." A simple and stupid joke, a careless remark, a straightforward criticism of actions and policies of the state of Israel, etc.-anything like this might be taken as an expression of "antisemitism." ${ }^{13}$ As could and should, of course, also conscious discrimination and violent terrorist attacks on Jews and anything Jewish.

Using the term "antisemitic" without further specification of how and why does not help either understanding or contribute to bringing it to an end. Quite the contrary. A sloppy and frivolous labeling of "antisemitic," for anything we perceive as a threat, or just don't like, or for some political reason want to fight will in the long run be counterproductive and even cause self-harm to the Jewish cause. There are three reasons for this:

(a) There is a risk that by overusing the term "antisemitism" we hollow and disarm the very concept of "antisemitism." The danger built into this is that in the end people and institutions will tend not to take even valid accusations of antisemitism seriously.

(b) There is also another danger in this: incessant descriptions of even trivial, but perhaps dubious aspects of the reality we live in as "antisemitic" tend to foster unnecessary fear among us. However, to further such a sense of fear might even be the aim of some of those who tend to overuse the notion of antisemitism in describing a situation.

(c) We also have to realize that an accusation of "antisemitism" is sometimes used polemically just to defend a position or to promote a certain political cause -even if what is accused is in fact not an expression of actual Jew-hatred. This also inevitably promotes mistrust toward the very concept "antisemitism" itself.

For both political and ethical reasons, we need to protect the concept "antisemitism" from abuses such as those indicated above. Antisemitism is a harsh real-life reality, to have a "clean" and clearly understandable notion "antisemitism" to grasp this real-life phenomenon to be able adequately to counter it, is very much needed. Hence, Jews as well as non-Jewish champions for equal and human rights ought to be careful and restrained in accusing anyone of "antisemitism." And also, when it is actually relevant to do so, as it unfortunately too often is, supplement any such accusation with a relevant reason or argument clarifying why the utterance or action taken to be "antisemitic" actually is so.

13 I might myself be one of these oversensitive Jews. 
Otherwise, ubiquitous labelling of things as "antisemitic" is not merely abuse: it will boomerang the Jewish position itself.

\section{Intended Over-interpretations-Unintended Symbioses}

Antisemitic attacks on Jews are still ubiquitous in the world of today. As noted, such attacks in certain parts of Europe mainly emanate from classic antisemitic stereotypes. They then often take the form of derogatory remarks, sometimes subtle forms of discrimination and at times turn into elaborate conspiracy theories about Jews worldwide controlling the world, or aiming to do so, through a secret conspiracy-run by "globalists," pulling the threads of a supposed "deep state."

In other parts of Europe and the world, antisemitic attacks mainly emanate from hatred toward the state of Israel and actions taken by Israel. This then at times is manifested in violent attacks on Jewish institutions and individual Jews anywhere in the world. The argument goes as follows: because they are Jewish the targeted people/institutions are seen to be linked with Israel by these perpetrators, subsequently they are regarded as relevant targets in the perpetrators' "fight against Israel."

Heavily exaggerated and evil-minded accusations toward Israel are ubiquitous in today's political discourse. Part of this negative focus on anything done by Israel is certainly carried by projections of classic Jew-hatred. It is necessary and important to point out and report all manifestations of antisemitism and to do whatever is relevant to hinder any potential antisemitic hate speech, discrimination, and violence. However, to exploit and even abuse such events for other, often not openly stated, political purposes may both corrupt and eventually disarm the very fight against antisemitism.

The rather recent notion of the "New Antisemitism" becomes relevant in this context. This concept attempts to capture what by some is regarded as a new kind of antisemitism that has appeared in the late twentieth and early twentyfirst centuries. According to adherents of the concept, this kind of antisemitism is manifested in certain initiatives at combatting Zionism and manifests opposition to actions and policies by the state of Israel. Within the optics of this concept, what purports to be criticism of Israel is in fact tantamount to the demonization of the state of Israel. This demonization then, according to the concept, is in itself a kind of antisemitism. 
"Israel-derived antisemitism," however, is something else. It denotes very precisely those verbal accusations or violent attacks directed toward individual Jews and/or Jewish institutions in the diaspora that are carried out with reference to, that is, "legitimated" in the eyes of the perpetrators, by what they imagine the state of Israel is, has done, or supposedly intends to do.

It is necessary to distinguish clearly between what is referred to by the notion the "new antisemitism" and what I refer to by the concept "Israel-derived antisemitism." "Israel-derived antisemitism" refers exclusively to attacks on individual Jews or Jewish institutions, mainly in the diaspora, emanating from the perpetrator's hostility toward the state of Israel and/or anger due to actions taken by the Israeli state. The concept "new antisemitism," however, refers to hateful critique and certain forms of opposition the state of Israel itself.

When harsh critique and actions of protests directed toward Israel are perceived as overly exaggerated, unfair, hostile, and unjustified, the concept of "New Antisemitism" is taken to be another expression of antisemitism. Since "antisemitism" is nowadays a strong taboo in all Western and democratic countries, but hateful attitudes toward the state of Israel and "anti-Zionism" are not, expressions of such attitudes and actions manifesting strong opposition to the state of Israel, such as agitation for the boycott of Israeli products and the like, are within the frame of the New Antisemitism concept seen as just "antisemitism in disguise." To substantiate the IHRA definition of antisemitism cited above, the IHRA present some examples of what according to them is antisemitism. Among these examples are:

a) Accusing the Jews as a people, or Israel as a state, of inventing or exaggerating the Holocaust.

b) Accusing Jewish citizens of being more loyal to Israel, or to the alleged priorities of Jews worldwide, than to the interests of their own nations.

c) Denying the Jewish people their right to self-determination, for example, by claiming that the existence of a State of Israel is a racist endeavor.

Doubt could be raised concerning whether some of these examples are truly antisemitic. For example, the notion that being so traumatized by the Holocaust that virtually everything in the world is perceived through this prism, the notion of being more loyal to Israel than to the state one happens to live in, or finding Israel is pursuing an apartheid-like politics-it is debatable whether these standpoints are actually antisemitic. Many concerned Jews of the world today would be doomed antisemites if this were the case.

Several concerned Jewish scholars and intellectuals have consequently launched critiques both of the concept the "New Antisemitism," and of the situations that IHRA are presenting as examples of antisemitism. They argue that 
it conflates anti-Zionism with antisemitism, defines legitimate criticism of Israel too narrowly and demonization too broadly, trivialises the meaning of antisemitism, and exploits antisemitism in order to silence political debate about Israeli actions and policies. ${ }^{14}$

The abuse of the concept "antisemitism" and a tendency to over-interpret incidents that may comprise antisemitic elements in an alarmistic way, may cause an ironic symbiosis could occur:

On the one side, the interest of terrorists and other violent Jew-haters is to harm and cause anxiety and fear among Jews. On the other side, insistent and exaggerated remarks by, for example, Israeli officials and certain right-wing Zionist organizations claiming that Jews in Europe and elsewhere in the diaspora live in a basically antisemitic environment in which a latent but still constantly present antisemitism will unavoidably in different ways "show its ugly face" and harm, also kill, Jews living there, in effect serves the same purpose: to cause anxiety and fear among Jews.

"Friendly warnings" of latent threats and potential antisemitic attacks may of course be both well-founded and well-intended. However, there is a tendency for them to become exaggerated and alarmist. Sometimes they emanate from incidents that many would perhaps regard as course and scurrilous, but by a hyper-sensitive observer (as Jews for very good reasons often are) could be interpreted as having a perhaps veiled but still antisemitic component.

Some "friendly warnings" have other backgrounds. They may rather be calculated and conscious over-interpretations in order to stir up fear among Jews for political purposes other than fighting actual antisemitism. Here are two examples from my own corner of the world, Sweden:

Malmoe is the third largest city of Sweden. In 2012, this city became world famous for repeated antisemitic incidents largely consisting of harassments of an orthodox rabbi. Furthermore, an openly manifested anti-Israeli atmosphere prevailed there, partly tolerated by the city's former mayor Ilmar Reepalu, who has since left office.

14 Cf. e. g. B. Klug, “The Myth of the New Anti-Semitism,” The Nation, January 15, 2004, https:// www.thenation.com/article/archive/myth-new-anti-semitism/; B. Lewis, "The New Anti-Semitism: First Religion, then Race, then What?," The American Scholar 75, no. 1 (2006): 25-36; M. Lerner, "There is no New Anti-Semitism," The Baltimore Chronicle, February 2, 2007, http://baltimorechronicle.com/2007/020207LERNER.shtml; A. Lerman, "Jews Attacking Jews,” Haaretz, September 12, 2008, https://www.haaretz.com/1.5029448; B. Klug, “Interrogating 'New Anti-Semitism'," Ethnic and Racial Studies 36, no. 3 (2013): 468-82. 
Karolinska is a very renowned hospital in Stockholm. ${ }^{15}$ In 2018, a leading surgeon and a whole department at Karolinska was accused of antisemitically motivated discrimination and spreading of antisemitism.

In both cases the Simon Wiesenthal Centre, located in Los Angeles, reacted very strongly. In the case of Malmoe, they suggested that Jews boycott going there. In the case of Karolinska, in December 2018, they put the incidents at Karolinska on their list of the ten worst antisemitic incidents in the world that year.

However, the Jewish community in Malmoe was not in accord with the condemnation of the city launched by the Simon Wiesenthal Center. On the contrary, they opposed it and expressed a desire to work in close cooperation with the city authorities to curb the antisemitic incidents that emanated from sectors of Muslim inhabitants in Malmoe. This is still an ongoing process.

With respect to what happened at the Karolinska hospital in Stockholm, an independent investigation was launched to find out whether the accusations of antisemitic discrimination and the spreading of antisemitic material could be substantiated. The investigation concluded that there was no evidence supporting the accusations. However, the investigation also found that the accused leading surgeon, Dr. Inti Peredo, had reacted to Israel's handling of Palestinians in Gaza in an improper way, which Dr. Peredo also admitted to.

Both in the case of Malmoe and in the case of Karolinska, the Simon Wiesenthal Center consciously grossly overexposed and overreacted to what had actually taken place. The political reasons for this seem to be twofold: (1) To blur the distinction between opposition to Israel and antisemitism, and (2) to exploit incidents that in some sense comprise antisemitic elements in order to fan anxiety and induce Jews in these and other places of the diaspora to make aliyah, that is, the move to Israel as "the only safe place for Jews."

Given this and other examples, we encounter what appears to be a symbiotic relationship. On the one hand we have statements and actions done with clearly antisemitic aims, on the other hand we have some measures allegedly taken to point out the ever-threatening antisemitism-even if basically for political reasons other than to protect against antisemitism. Both foster fear and anxiety among Jews. Basically, even if unintentionally, the one side profits from the actions by the other side.

One intended effect of blurring the distinction between opposition to Israel and antisemitism is that criticism and opposition to what Israel is doing will become perceived as expressions of antisemitism. But by this, the very concept of

15 The Karolinska Institute awards the Nobel prize in medicine. 
antisemitism also tends to become excavated. This may have serious consequences, because in order to be able to confront and combat Jew-hatred, in particular of the kind that today manifests itself by violent attacks on Jewish persons and institutions (of the kind that has actually taken place in Malmoe), a clear and undisputable concept of antisemitism is an indispensable tool. A too frivolous use of the term "antisemitism," for instance for the sake of defending questionable actions and policies by the state of Israel, or in order to smear its critiques, contributes to draining the strength of the concept in the fight against real-life antisemitism.

To what degree, then, do Jews in Europe actually consider people antisemitic if they criticizes Israel?

\begin{tabular}{llll}
\hline & overall, in \% & “probably," in \% & “definitely," in \% \\
\hline Latvia & 43 & 37 & 6 \\
France & 41 & 28 & 13 \\
Hungary & 37 & 28 & 9 \\
Italy & 36 & 27 & 9 \\
Belgium & 34 & 23 & 11 \\
Germany & 32 & 27 & 5 \\
UK & 32 & 26 & 6 \\
Sweden & 22 & 17 & 5 \\
\hline
\end{tabular}

Table 5: Would you consider a non-Jewish person antisemitic if he/she criticizes Israel? (Data from the 2012 FRA Survey).

We find that generally just a very minor portion of Jews in the eight investigated EU states do think that a person who criticizes Israel is "definitely" antisemitic. Taking also the response alternative "probably" into account we find a rank order between the participating states that is very similar to the rank order we found in mapping the proportion of classic antisemitism in the countries (cf. Table 1). We see that among the countries with the highest proportion of classic antisemitism in the population, we also have the largest proportion of Jews who perceive criticism of Israel as antisemitic. At the other end we again find Sweden being outstanding: Sweden is the country with the lowest proportion of persons with classic antisemitic attitudes in their population, and in Sweden we also find that Jews to a lesser extent than anywhere else would consider a person antisemitic if he/she criticizes Israel.

However challenging the correspondence may appear, there is no evidence that there is a causal relationship here. 
Let's take it one step further:

\begin{tabular}{llll}
\hline & overall, in \% & “probably," in \% & “definitely," in \% \\
\hline France & 85 & 59 & 26 \\
Italy & 80 & 52 & 28 \\
Germany & 79 & 51 & 28 \\
Hungary & 77 & 43 & 34 \\
Latvia & 76 & 33 & 43 \\
Belgium & 74 & 47 & 27 \\
UK & 65 & 33 & 32 \\
Sweden & 53 & 24 & 29 \\
\hline
\end{tabular}

Table 6: Would you consider a non-Jewish person to be antisemitic if he or she supports boycotts of Israeli goods/products?

A majority of Jews in all of the studied countries regard boycotting of Israeli products antisemitic. A majority of Jews in Sweden also do so, however to a somewhat lesser extent than in the other countries. But like in the other countries about one third of the respondents mark that they "definitely" regard boycotting Israel "antisemitic."

It should be noted that in Israel, the international BDS movement, which promotes boycotts, divestments, and sanctions against Israel, as well as active support of this movement is, regarded as criminal (Israeli laws from 2011 and 2017). Organizations such as the Anti-Defamation League and the Simon Wiesenthal Center have proclaimed BDS "antisemitic." However, some Jewish human rights and leftist organizations such as Jewish Voice for Peace as well as individual Jewish intellectuals and celebrities, such as Judith Butler, openly support the BDS initiative.

\section{Dilemmas in the New Phase of Antisemitism}

I will conclude by pointing out two serious ethical, and also political, dilemmas in the contemporary political discourse, colored as it is by raising populist and illiberal tendencies.

(1) Over the last decades right-wing and populist parties and movements have gained growing success in many parts of the world, not least in countries in Europe and the USA. Several of these parties and movements harbor sometimes openly, but more often modestly veiled, antisemitic elements. Among them, for example, Sverigedemokraterna [The Sweden Democrats], Front (now Rassemblement) National in France, Jobbik and also Fides in Hungary, etc. At 
the same time several of these, and also governments run or influenced by them, like the present leaderships in Hungary, USA, but also Austria, Poland, and the Czech Republic ostentatiously support Israel. How come?

One underlying reason is their rather outspoken anti-Muslim and anti-Arab stance. Israel in the view of these parties and movements is understood as a kind of champion in the, according to them, necessary struggle of civilizations against non-Western and-as it is tacitly understood-anti-Christian forces. However, their demonstrative and often symbolic support for Israel, ranging from, for example, serving Israeli wine at the party convention (as done by the Dansk Folkeparti [Danish People's Party], to acknowledging Jerusalem as the capital of the state of Israel (as done by the USA, the Czech Republic, and Taiwan) may also, in addition to other interests, serve as a fig leaf to cover their underlying antisemitic roots. This applies, for instance, to Sverigedemokraterna in Sweden and Rassemblement National in France. It may also be in order to blur their antisemitic positions, as in Hungary where Orbán's idea of constructing an "illiberal democracy" and the backing of Israel is accompanied by a poorly disguised antisemitically colored campaign targeting "George Soros"-the originally Hungarian Jew who has devoted his life and money to promote liberal values and human and democratic rights.

This illustrates a new phase in the history of antisemitism, a phase in which Jewry will confront new ethical and political dilemmas.

On the one hand acknowledging the right of Israel to exist and flourish as a free and democratic state, on the other hand questioning the moral and political costs implied in supporting certain actions and policies of the state of Israel. Should one accept that even antisemitic features, elements, and tendencies among insistent right-wing populist supporters of Israel be overlooked and even tolerated, just because of their parallel support for Israel? Or should one as a concerned Jew and champion of human rights and democratic values unveil and confront antisemitism also when it means ripping off the fig leaf of demonstrative Israel support on political bodies like, for example, Viktor Orbán, Donald Trump, and the anti-Muslim populist parties in many of the European countries?

(2) By extension of the just stated, another ethical dilemma for Jews, but not only for Jews, in the contemporary political field emerges: the predicament of having to choose between (a) supporting the strategic interests of Israel or (b) defending and promoting Jewish values. Recent developments in Hungary may again serve as a case in point. As stated and well-known, the government of Hungary has run an antisemitically infected campaign against "the Jew George Soros"-a contemporary counterpart to "the plutocratic Jew Rothschild" in a previous phase of antisemitic discourse. On the surface the campaign might look as directed at Mr. Soros as a person, but more profoundly it is launched in 
order to counteract what "Soros" represents: an open society, liberal values, the idea of enlightenment, individual freedom, universal human rights, free trade, globalization, and cosmopolitanism. To many Jews this corresponds very well with what is understood to be also basic values of modern Judaism.

A further deepening of this dilemma arises as the Israeli prime minister Benjamin Netanyahu, in spite of the antisemitic features and elements in the campaign against "the Jew George Soros," openly bonds with Mr. Orbán and his government. Even to the extent of launching also in Israel-in Israel!-a campaign against "Soros." 16

One way of interpreting this is that Israel, and by implication some of those Zionist groups in other countries that tend to defend whatever Israel is doing, gives priority to promoting Israeli national interests over promoting Jewish values. And this even at the cost of disregarding, and by implication tolerating, the antisemitic elements that join in the support of Israel.

It seems we are confronting an emerging and growing contradiction between fundamental Jewish values and the strategic and national interests of the state of Israel. In the wake of this, the notion "antisemitism" tends to become expanded and diluted. The risk is the concept "antisemitism" will become useless in the necessary fight against real-life antisemitism. The ethical and political costs involved in this development need to be seriously contemplated.

Lars Dencik lives in Sweden and is professor emeritus of social psychology at Roskilde University, Denmark. His research focuses on the implications of societal modernization on relations between individuals and groups, in particular on Jewish life and antisemitism in Europe. He is part of the international research team investigating experiences and perceptions of antisemitism among Jews in different European states based at Institute for Jewish Policy Research in London.

\section{References}

Anti-Defamation League. “ADL Global 100.” Accessed December 28, 2020. https://global100. adl.org/map.

Bauman, Zygmunt. Modernity and the Holocaust. Cambridge: Polity, 1991.

16 Cf. H. Ben-Sasson, “Attacking Soros: Israel's Unholy Covenant With Europe’s anti-Semitic Ultra-right,” Haaretz, July 12, 2017, https://www.haaretz.com/opinion/attacking-soros-israelsunholy-covenant-with-europes-anti-semitic-ultra-right-1.5493531. 
Ben-Sasson, Hillel. "Attacking Soros: Israel's Unholy Covenant With Europe's anti-Semitic Ultra-right." Haaretz, July 12, 2017. https://www.haaretz.com/opinion/attacking-soros-is raels-unholy-covenant-with-europes-anti-semitic-ultra-right-1.5493531.

Dencik, Lars. "Antisemitisms in the Twenty-First Century: Sweden and Denmark as Forerunners?" In Antisemitism in the North: History and State of Research, edited by Jonathan Adams and Cordelia Hess, 233-68. Berlin: De Gruyter, 2019.

Dencik, Lars, and Karl Marosi. Different Antisemitisms: Perceptions and experiences of antisemitism in Sweden and across Europe. London: Institute for Jewish Policy Research, 2017.

European Agency for Fundamental Rights (FRA). Discrimination and Hate Crime against Jews in EU Member States: Experiences and Perceptions of Antisemitism. Luxembourg: Publications Office of the European Union, 2014.

European Agency for Fundamental Rights (FRA). Experience and Perceptions of Antisemitism: Second Survey on Discrimination and Hate Crime against Jews in the EU. Luxembourg: Publications Office of the European Union, 2018.

Færseth, John. "Johan and Antisemitism.” Fri Tanke, November 12, 2020. https://fritanke.no/ bakgrunn/johan-galtung-and-antisemitism/19.11455.

International Holocaust Remembrance Alliance. "Working Definition of Antisemitism." Issued May 26, 2016. Accessed May 23, 2021. https://www.holocaustremembrance.com/news-ar chive/working-definition-antisemitism.

Klug, Brian. “Interrogating ‘New Anti-Semitism'.” Ethnic and Racial Studies 36, no. 3 (2013): $468-82$.

Klug, Brian. "The Myth of the New Anti-Semitism." The Nation, January 15, 2004. https:// www.thenation.com/article/archive/myth-new-anti-semitism/.

Lerman, Anthony. “Jews Attacking Jews.” Haaretz, September 12, 2008. https://www.haaretz. com/1.5029448.

Lerner, Michael. "There is no New Anti-Semitism.” The Baltimore Chronicle, February 2, 2007. http://baltimorechronicle.com/2007/020207LERNER.shtml.

Lewis, Bernard. "The New Anti-Semitism: First religion, then race, then what?" The American Scholar 75, no. 1 (2006): 25-36.

World Value Survey. “Findings \& Insights.” Accessed December 28, 2020. http://www.worldva luessurvey.org/WVSContents.jsp?CMSID=Findings.

Zimmermann, Moshe. Wilhelm Marr, the Patriarch of Anti-Semitism. Oxford: Oxford University Press, 1986. 
